\title{
Faaliyet İzninin Kaldırılmasının Vakıf Üniversitesi Öğrencileri Bakımından Etkileri
}

\author{
Withdrawal of Activity Permit Effects for Foundation University \\ Students
}

Ebru Zeybek Cebeci ${ }^{*}$ (iD)

\section{öz}

Çalışmamızın amacı faaliyet izinleri kaldırılan vakıf üniversitelerinin öğrencilerinin eğitim ve öğretim faaliyetlerine ilişkin işlemlerinin nasıl yapılacağının değerlendirilmesidir. Bu kapsamda öncelikle vakıf üniversitelerinin faaliyet izninin kaldırılmasına ilişkin hukuki düzenlemelere yer verilecek, ardından faaliyet izni kaldırılan vakıf üniversitelerinin öğrencilerinin durumu üzerine değerlendirme yapılacaktır.

Anahtar Kelimeler: Vakıf Üniversiteleri, Faaliyet İzninin Kaldırılması, Öğrencilerin Eğitim ve Öğretim Faaliyetine İlişkin İşlemler.

\section{ABSTRACT}

The aim of our study is to evaluate how the procedures regarding the education and training activities of the students of foundation universities whose activity permits are revoked will be carried out. In this context, first of all, legal regulations regarding the abolition of the operating permits of foundation universities will be included, and then an evaluation will be made on the status of the students of foundation universities whose activity permits have been revoked.

Keywords: Foundation Universities, Withdrawal of Activity Permit, The Procedures Regarding the Education and Training Activities of The Students.

\section{FAALIYET IZNININ KALDIRILMASI}

Anayasảnın 130.maddesine göre vakıflar yükseköğretim kurumları, mali ve idari konuları dışında devlet yükseköğretim kurumlarıyla aynı Anayasal hükümlere tabidir. Dolayısıyla kamu tüzel kişiliğine sahiptir.

Anayasa gereğince vakıf üniversiteleri de tıpkı devlet üniversiteleri gibi kanunla kurulmaktadır. Yetki ve usulde paralellik ilkesi gereğince vakıf üniversitelerinin tüzel kişilikleri de yine ancak kanunla ortadan kaldırılabilecektir. Bununla birlikte 2547 sayılı Yükseköğretim Kanunu’nun ek 11.maddesinde yer alan düzenlemeyle belirli durumlarda vakıf üniversitelerinin faaliyetinin durdurulabilmesi ve faaliyetine son verilmesi mümkün kılınmıştır.

\footnotetext{
* Arş.Gör.Dr., Marmara Üniversitesi Hukuk Fakültesi İdare Hukuku Anabilim Dalı Sorumlu Yazar/Correspondence Author: Ebru Zeybek Cebeci
}

E-posta/E-mail: ebru.zeybek@marmara.edu.tr 
Anılan maddeye göre vakıf üniversitelerinde beklenen eğitim-öğretim düzeyinin yetersiz olduğunun Yükseköğretim Kurulunca tespit edilmesi ve durumun düzeltilmesi için gerekli uyarı ve önerilerin sonuçsuz kalması halinde bu kurumun faaliyeti Yükseköğretim Kurulunca durdurulacaktır. Ayrıca vakıf üniversitesince kurucu vakfa veya üçüncü şahıslara kaynak aktarıldığının Maliye Bakanlığının görüşü alınarak Yükseköğretim Kurulunca tespit edilmesi halinde verilen süre içinde kaynağın vakıf üniversitesine iadesi sağlanmazsa Yükseköğretim Kurulu tarafından düzeltici, kısıtlayıcı veya faaliyet iznini kaldırma şeklinde tedbir niteliğinde kararlar alınabilecektir.

Denetimler sonucunda faaliyet izninin kaldırılmasını gerektiren bir durum tespit edilmesi halinde bu vakıf üniversitelerinin ve kurucu vakfına kayyım atanan vakıf üniversitelerinin faaliyet izni, Cumhurbaşkanı kararı ile kaldırılmaktadır. Ancak vakıf üniversitelerinin faaliyet izni kaldırıldığında da tüzel kişiliği devam etmektedir. Tüzel kişiliğin kaldırılmasının sağlanması için vakıf üniversitesinin faaliyet izni kaldırıldı̆̆ında durum Yükseköğretim Kurulu tarafından Millî Eğitim Bakanlığına bildirilecektir.

Vakıf üniversitelerinin faaliyet izninin kaldırılmasını gerektiren haller 2547 sayılı Kanun'da açık bir şsekilde düzenlenmemiştir. Bu hususa ilişkin düzenleme her ne kadar Vakıf Yükseköğretim Kurumları Yönetmeliğiyle yapılmışsa da yönetmelikte yapılan düzenlemede de kanunda yer alan "vakıf üniversitelerinde beklenen eğitim - öğretim düzeyinin yetersiz"liğine ilişkin objektif kriterler getirilmediği, ayrıca "vakıf yükseköğretim kurumu yöneticilerinin ülkenin bölünmez bütünlügüne karşı eylemleri doğrudan işlemesi veya bu tür eylemleri desteklemesi” gibi eğitimöğretim faaliyetiyle ilgisi olmayan ve kapsamının sınırları belirli olmayan, zamana göre değişebilen ifadelerle1, "mal varlığı unsurlarının vakıf yükseköğretim kurumunun faaliyetini sürdürmeye imkân vermeyecek ölçüde kaybedildiğinin tespit edilmesi” gibi keyfiyete elverecek muğlak ifadelere yer verildiği görülmektedir. Ancak bu durum çalışma konumuz dışında kaldığından çalışmamızda ilgili hükümlere değinmekle yetinilecektir.

Vakıf Yükseköğretim Kurumları Yönetmeliği’nin 25.maddesinin ilk fıkrası (e) bendinde vakıf üniversitelerinin faaliyet izinlerinin kaldırılıp üniversitenin kapatılmasına sebep olacak haller tahdidi olarak sayılmıştır. Buna göre;

“1) Vakıf yükseköğretim kurumunun, kuruluş tarihinden itibaren üç yıl içinde eğitim öğretime başlamaması,

2) Vakıf yükseköğretim kurumunun eğitim-öğretim, yayın, danışmanlık, ticari ve diğer faaliyetleri ile bağışlardan elde ettiği gelirini, yükseköğretim kurumunun akademik faaliyetlerini, yatırım ve cari giderlerini finanse etmekte kullanmadığının tespit edilmesi,

3) Vakıf yükseköğretim kurumu kurucu vakfı veya vakıfları tarafından kuruluşta taahhüt edilen harcamaların yükseköğretim kurumu gelirlerinden karşılanması,

1 Turan Yıldırım, 'Vakıf Üniversitelerinin Denetlenmesi', MÜHF-HAD, C.21, S.2,Y.2015, s. 470-471 
4) Alım, satım ve ihalelerde vakıf yükseköğretim kurumunu zarara uğratıcı nitelikte usulsüzlük yapılması,

5) Vakıf yükseköğretim kurumu yöneticilerinin ülkenin bölünmez bütünlüğüne karşı eylemleri doğrudan işlemesi veya bu tür eylemleri desteklemesi,

6) Kurucu vakıf tarafından vakıf yükseköğretim kurumunun kuruluş aşamasında kuruluş taahhüdü olarak devir, temlik ve taahhüt edilen mal varlığı unsurlarının vakıf yükseköğretim kurumunun faaliyetini sürdürmeye imkân vermeyecek ölçüde kaybedildiğinin tespit edilmesi,

7) 28 inci maddede sayılan yöntemlerden herhangi biri ile vakıf yükseköğretim kurumundan kaynak aktarımı yapıldığının tespiti üzerine verilen süre içerisinde aktarılan kaynağın iade edilmemesi,

8) Vakıf yükseköğretim kurumu mütevelli heyeti seçilmesi, yenilenmesi ve üyeliklerinin sona erdirilmesinde hileli ve usulsüz işlemlerin yapılması"

hallerinde vakıf üniversitelerinin faaliyet izni kaldırılacaktır.

Ayrıca 2547 sayılı Kanun'un ek 11.maddesinin 14.fikrası ve anılan Yönetmeliğin 26.maddesine göre; faaliyet izni geçici olarak durdurulan vakıf üniversitelerinin, "eğitim-öğretim faaliyetleri için mülkiyetinde yeterli taşınmazı bulunmadığının veya mevcut malvarlığıyla eğitim-öğretim faaliyetlerini sürdüremeyeceği’"nin garantör üniversite tarafından tespit edilip, Yükseköğretim Kurulunca onaylanması halinde faaliyet izninin kaldırılacağı düzenlenmiş̧ir. Yine Yönetmeliğin 26.maddesine göre faaliyet izni geçici olarak durdurulan ve durdurulma süresi kesintisiz olarak üç yıl devam eden vakıf üniversitesinin faaliyet izni kaldırılacaktır.

\section{FAALIYET IZNININ KALDIRILMASININ ÖĞRENCILER BAKIMINDAN SONUÇLARI}

Vakıf üniversitelerinin faaliyet izninin kaldırılması sonucunda üniversitenin yönetimi garantör üniversiteye ya da aynı ilde bulunan ve Yükseköğretim Genel Kurulu tarafından belirlenen üniversiteye devredilecektir. Bu durum devredilen üniversitenin tüzel kişiliği sona erene kadar bu şekilde devam edecektir.

Vakıf üniversitesinin faaliyet izninin kaldırılması kararının verildiği tarihte mütevelli heyeti başkanı, üyeleri ile rektörü veya müdürünün görevleri sona ermektedir. Onların yerini yönetimi devralan üniversitenin yöneticileri alacak, devralan üniversitenin rektörü vakıf üniversitesinin geçici mütevelli heyeti başkanı, üniversite yönetim kurulu da geçici mütevelli heyeti olacaktır. Mütevelli heyeti toplantılarına Yükseköğretim Genel Kurulu’nun bir üyesinin de gözlemci olarak katılması gerekmektedir (Vakıf Yükseköğretim Kurumları Yönetmeliği, m.27/2).

Faaliyet izninin kaldırılması yalnızca vakıf üniversitesinin yönetiminin devredilen devlet üniversitesine geçmesine yol açmamakta, bu durum aynı zamanda öğrenciler bakımından da bir takım sonuçlar doğmaktadır. 
2547 sayılı Kanun'un 11.maddesi 15.fıkrasına göre "faaliyet izni kaldırılan vakıf üniversitelerinin eğitim öğretim ücretlerinin belirlenmesine, öğrencilerin nakline, eğitim öğretimin ve diğer işlemlerin aksamadan yürütülmesine ilişkin her türlü tedbirleri almaya ve düzenleme yapmaya Yükseköğretim Kurulu yetkili” bulunmaktadır. Anılan maddenin 17.fıkrasına göre ise; "Vakıf yükseköğretim kurumlarının denetimi ve bu denetim sonucu ilgili yükseköğretim kurumu hakkında yol gösterici, düzeltici, kısıtlayıcı veya faaliyet iznini kaldırıcı önlemlerin alınmasına ilişkin usul ve esaslar, Üniversitelerarası Kurulun görüşü alınarak Yükseköğretim Kurulu tarafından çıarılan yönetmelikle” düzenlenmektedir.

Bu kapsamda faaliyet izni kaldırılan vakıf üniversitelerinin öğrencilerinin öğrenim faaliyetlerine ne şekilde devam edeceği ve yapılacak işlemlere ilişkin hususlar Yükseköğretim Kurulu tarafından Vakıf Yükseköğretim Kurumları Yönetmeliği ve Garantör Devlet Üniversiteleri Yönergesiyle düzenlenmiştir.

\section{I - Öğrencilerin Devri ve Öğretim Faaliyetinin Sürdürülmesi}

2547 sayılı Kanun'un ek 11.maddesinin 3.fikrasında faaliyet izni kaldırılan vakıf üniversitesi öğrencilerinin garantör veya Yükseköğretim Kurulu tarafından belirlenecek aynı ildeki bir üniversiteye devredileceği belirtilmiş ancak ayrıntılı bir düzenlemeye gidilmemiştir.

Garantör Üniversite, Garantör Devlet Üniversiteleri Yönergesi’nin 3.maddesi 1.fikrası (a) bendinde "Vakıf yükseköğretim kurumunun faaliyetinin geçici olarak durdurulması halinde idaresinin, faaliyet izninin kaldırılması halinde öğrencilerinin de aktarılacağı kuruluş aşamasında Devlet üniversitesinin yetkili organınca karara bağlanarak belirlenen Devlet üniversitesi” olarak ifade edilmiştir. Vakıf Yükseköğretim Kurumlarının Kuruluş ve İşleyişine İlişkin Usul ve Esaslar’ın 11.maddesinde ise garantör devlet üniversitesinin "Kurulması planlanan vakıf yükseköğretim kurumuyla aynı ilde olması ve “Ondan fazla vakıf yükseköğretim kurumuna garantör olmaması”nın şart olduğu düzenlenmiştir.

Vakıf üniversitesi öğrencilerinin garantör üniversite dışında devredilebileceği üniversite ise, Garantör Devlet Üniversiteleri Yönergesi’nin 3.maddesinde, garantör üniversitenin kapasitesinin yeterli olmadığı durumlarda öğrencilerin aktarılacağı devlet üniversitesi olarak tanımlanmıştır.

Ancak ne ilgili Yönetmelikte ne de Yönergede garantör üniversitelerin kapasitesinin yeterli gelmemesi hali açıklanmamaktadır. Kapasiteden kastedilen öğrencilerin okutulabileceği yer ifade edilmek isteniyorsa bu durum daha çok garantör üniversite belirlenirken düşünülmesi gereken bir husus olarak görülmektedir. Eğer kapasiteden kastedilen gerekli programların mevcudiyeti ise mevzuatta faaliyeti durdurulan vakıf üniversitesinde olup garantör üniversitede olmayan programların açılacağının düzenlenmesi sebebiyle bu durumda da "garantör üniversitenin kapasitesinin yeterli olmadığı durumlar” ifadesi anlamlı görünmemektedir. Bununla birlikte garantör üniversiteler belirlenirken programların benzer olmasının dikkate alınmasının yararlı olacağı söylenebilecektir ${ }^{2}$.

2 Lale Burcu Önüt, "Vakıf Üniversitesinin Faaliyetlerinin Durdurulması ve Garantör Üniversitenin İşlevi”, İKÜHFD, C.17, S.1, Y.2018, s.111. 
Vakıf üniversitesi öğrencilerinin devredilen üniversitede öğrenimlerine devam etmesine ilişkin mevzuatımızda çeşitli hükümler bulunmakla birlikte, bu hususun tüm detaylarıyla yeterince düşünülmediği görülmektedir. Bu durum hem faaliyet izni sona eren vakıf üniversitesi öğrencilerinin hak kaybına uğramasına neden olabilecek hem de devredilen üniversiteleri yönetimsel olarak zorlayabilecektir. 2547 sayılı Kanun'un ek 11.maddesinin 16. fikrasında vakıf üniversitelerinin faaliyet izninin kaldırılmasına ilişkin maddenin uygulanmasında yaşanan tereddütleri gidermeye, gerektiğinde Maliye ve Millî Eğitim bakanlıklarının görüşünü alarak Yükseköğretim Kurulu yetkili olduğu düzenlenmiştir. Bununla birlikte bu yetkinin keyfiyet taşımaması, farklı uygulamalara mahal vermemesi için bir düzenlemeyle yapılması gereği kaçınılmazdır.

Mezkur Yönerge’nin 4.maddesi 2.fikrasına göre vakıf üniversitesi öğrencilerinin öğrenim görmekte olduğu programların devredilen üniversitede bulunmaması halinde, bu programların vakıf üniversitesinde okutulan eğitim dilinde devredilen üniversitede açılacağı düzenlenmiştir. $\mathrm{Bu}$ konuda devredilen üniversiteye bir seçim hakkı tanınmamıştır. Bununla birlikte vakıf üniversitesinde mevcut bir programın devredilen üniversitede de var olması ancak aynı eğitim dilinde olmaması halinde ne yapılacağına ilişkin bir düzenleme bulunmamaktadır. Yalnızca devredilen üniversitede var olmayan programlar özelinde bu şekilde düzenleme yapılması, diğer ihtimal halinde devredilen üniversitenin söz konusu programları vakıf üniversitesiyle aynı eğitim dilinde okutmaya ilişkin bir zorunluluğu olmadığ ş̧eklinde yorumlanabilecektir. $\mathrm{Bu}$ durumda örneğin eğitim dili İngilizce olan bir bölümü kazanarak öğrenim gören vakıf üniversitesi öğrencilerinin devredilen üniversitede Türkçe eğitim görmesi söz konusu olabilecektir. Bununla birlikte Yönerge’nin 7.maddesi 2.fikrasında faaliyet izni kaldırılan vakıf üniversitesinde bir programda Türkçe öğrenim gören öğrencilerin devredilen üniversitede programın Türkçe olarak bulunmaması halinde yabancı dilde eğitim olan programa geçebileceği ancak bu durumda öncelikle dil yeterliliğini devredilen üniversitenin koşullarına göre başarıyla tamamlaması gerektiği düzenlenmiştir. Kanımızca hak kaybı oluşmaması için var olan programları okutulan dille bir bütün olarak düşünmek gerekmektedir. Örneğin devredilen devlet üniversitesinde uluslararası ilişkiler bölümünün olması ancak programın Türkçe olması halinde, kapatılan vakıf üniversitesinde İngilizce Uluslararası İlişkiler bölümünde okuyan öğrenci açısından okuduğu programın devredildiği devlet üniversitesinde olmadığı anlamına geldiğinin kabul edilmesi ve yönerge kapsamında bu programın açılması daha uygun görünmektedir. Bir diğer çözüm ise kanımızca mevzuatta gerekli düzenlemeye gidilerek öğrencilerin öğrenim görmekte olduğu programın devlet üniversitesinde aynı dilde mevcut olmaması halinde öğrenciye tercih hakkı verilmesi ve belirlenen kriterler çerçevesinde başka bir üniversiteye devrinin sağlanması olabilecektir.

\section{2 - Öğrencilerin Yeniden Yerleştirilmesi}

İlgili mevzuatta öğrencilerin devrinde tercihlerine göre yeniden yerleştirme yapılabileceğine ilişkin düzenlemeler de bulunmaktadır. Garantör Devlet Üniversiteleri Yönergesi’nin 5.maddesine göre "Aynı anda birden fazla vakıf yükseköğretim kurumunun kapatılması halinde; kapatılan vakıf 
yükseköğretim kurumlarının öğrencilerinin tercihlerine yerleştirilmesinde öğrencinin kayıt olduğu yıla ait ilgili puanı dikkate alınır ve tercih edilen programın ilgili yıla ait taban puanının öğrencinin puanından düşük veya puanına eşit olması durumunda yerleştirme" yapılacaktır.

Maddede açıkça belirtilmiyorsa da, "aynı anda birden fazla vakıf yükseköğretim kurumunun kapatılması" ifadesinden kastedilen kanımızca aynı garantör üniversitenin belirlendiği birden fazla vakıf üniversitesinin faaliyet izninin aynı anda kaldırılması ve/veya aynı ilde öğrencilerin devredileceği tek devlet üniversitesinin bulunmasına rağmen birden fazla vakıf üniversitesinin faaliyet izninin aynı anda kaldırılması olmalıdır, böylece devredilecek devlet üniversitesinin öğrenci kapasitesi sınırının aşılması engellenmeye çalışılmış olmalıdır. Aksi halde aynı anda birden fazla vakıf üniversitesinin kapatılması hususunda, öğrencilerin devrine ilişkin esaslara ek düzenleme getirilmesinin nedenini saptamak bir hayli zor görülmektedir. Örneğin garantör üniversitesi (A) Üniversitesi olarak belirlenen ve İzmir'de bulunan vakıf üniversitesi ile garantör üniversitesi (B) Üniversitesi olarak belirlenen ve İstanbul'da bulunan vakıf üniversitesinin aynı anda faaliyet izninin kaldırılması ek bir düzenleme gerektirmeyecektir. Yine aynı ilde bulunan ancak garantör üniversiteleri farklı birden fazla vakıf üniversitesinin faaliyet izninin aynı anda kaldırılması birbirinin durumunu etkilemeyecektir.

Anılan maddenin 2.fikrasında öğrencilerin tercih ettiği programlardan birine yerleştirilememesi halinde uygulanacak usul de düzenlenmiştir. Buna göre tercih ettikleri programlardan birine yerleşememesi halinde öğrenciler, ilgili yılda öğrencinin puanından düşük veya puanına eş puanla öğrenci alan bir program olması halinde taban puanı öğrencinin puanına en yakın olan programa yerleştirilecektir. Puanlarının ilgili yıldaki programların taban puanlarından düşük olması halindeyse öğrenciler, ilgili yıldaki en düşük taban puanlı programa yerleştirilecektir.

Maddenin üçüncü fikrasında ise yeniden yerleştirmeye ilişkin yönerge kapsamında bulunmayan konularda ilgili mevzuat hükümlerinin saklı tutulduğu düzenlenmiştir.

Yönergède yeniden yerleştirmeye ilişkin yapılan bir düzenleme de yabancı öğrencilere ilişkindir. Yönergenin 6.maddesine göre faaliyet izni kaldırılan vakıf üniversitesinde öğrenim görmekte olan yabancı uyruklu öğrencilerin kayıtlı oldukları programın garantör üniversitede bulunmaması halinde yabancı uyruklu öğrencilerden tercih alınarak Yükseköğretim Kuruluna bildirilecek ve bu öğrenciler Yükseköğretim Kurulu tarafından başka bir üniversiteye yerleştirilecektir.

Kanımızca Yönerge’nin yeniden yerleştirmeye ilişkin düzenlemelerinde 667 Sayılı KHK İle Kapatılan Vakıf Yükseköğretim Kurumlarının Önlisans ve Lisans Programlarındaki Öğrencilerin İşlemleri ile İlgili Usul ve Esaslar'dan esinlenilmiştir. Ancak bu çok uygun bir tercih olarak görülemeyecektir. 667 Sayılı KHK ile kapatılan vakıf yükseköğretim kurumları öğrencilerinin aktarılacağı belirli bir garantör üniversite bulunmamaktadır. Yalnızca bu öğrencilerin belirli işlemlerini yapmakla yetkili, koordinatör üniversiteler belirlenmiştir ve öğrenciler temel olarak tercihleri doğrultusunda yükseköğretim kurumlarına yerleștirilmektedir. 2547 sayılı Kanun’un ek 11.maddesi ve ilgili mevzuat kapsamında faaliyetine son verilen vakıf üniversitelerinin öğrencilerinin durumu ise farklıdır. $\mathrm{Bu}$ öğrenciler garantör üniversiteye, garantör üniversitenin kapasitesinin yeterli olmadığ durumlarda ise Yükseköğretim Kurulu tarafından belirlenecek aynı ildeki bir devlet üniversitesine devredilmektedir. 
Bununla birlikte mevzuatta gerekli düzenlemeler yapılarak 2547 sayılı Kanun'un ek 11.maddesi kapsamında faaliyetine son verilen üniversitelerin öğrencilerinin okumakta oldukları programın devredilen üniversitede bulunmaması halinde bu öğrencilere tercih hakkı verilerek belirli koşullar altında devredilen üniversiteden başka bir üniversiteye aktarımlarının sağlanması mümkündür. Ancak bu öğrencilerin yeniden yerleştirmeye ilişkin mevzuat hükümleri kapsamında düzenlenmeyen eğitim ve öğretim faaliyetlerine ilişkin olarak garantör üniversiteye aktarılan öğrencilerle aynı mevzuat hükümlerinin geçerli olduğunun da göz önünde tutulması gerekecektir.

\section{3 - Diploma işlemleri ve Devredilen Öğrencilere Uygulanacak Mevzuat Hükümleri}

Vakıf Yükseköğretim Kurumları Yönetmeliğinnin 27/4. maddesine göre faaliyet izni kaldırılan vakıf üniversitesinden devredilen öğrencilerden vakıf üniversitesinin tüzel kişiliği kaldırılıncaya kadar öğrenimini tamamlayanlar vakıf üniversitesinin diplomasını alacaklardır. Bu durumda vakıf üniversitesinin yönetimi devredilen üniversiteye geçtiğinden, tüzel kişilik sona erene kadar öğrencilere, devredilen üniversitenin yöneticisi tarafından imzalanmakla birlikte vakıf üniversitesinin diploması verilecektir.

Tüzel kişiliğin sona erdiği tarihten itibarense eğitim-öğretimine devredilen üniversitede devam eden ve mezun olan öğrencilere devredilen üniversitenin diploması verilecektir. İlgili Yönetmeliğin 27.maddesinin 3. fıkrasına göre "Eğitim öğretime fiilen devam eden öğrenci sayısının, vakıf yükseköğretim kurumunun faaliyet izninin kaldırıldığ 1 tarihteki mevcut öğrenci sayısının \%10’unun altına düşeceği tarihte faaliyet izni kaldırılan vakıf yükseköğretim kurumunun kuruluş kanununun veya Bakanlar Kurulu Kararının yürürlükten kaldırılması için durum Milli Eğitim Bakanlığına” bildirilecektir ${ }^{3}$. Düzenlemenin nedenini anlamak güç olsa da, bu durumda vakıf üniversitesinin faaliyet izninin kaldırıldığı tarihte mevcut öğrenci sayısının $\% 10$ ’u sınavla yerleștirilmediği ancak devredildiği devlet üniversitesinin diplomasını alacaktır.

Mevzuatımızda devredilen vakıf üniversitesi öğrencilerine hangi üniversitenin düzenlemelerinin uygulanacağına ilişkin bir hüküm bulunmamaktadır. Devredilen vakıf üniversitesinde eğitim öğretim faaliyeti sona erdiği için bu faaliyete ilişkin düzenlemelerin yürürlüğünü korumayacağı düşünülebilecektir. Bununla birlikte kanımızca faaliyet izni kaldırılan vakıf üniversitesinin tüzel kişiliği devam ettiği sürece vakıf üniversitesinin düzenleyici işlemleri de geçerliliğini koruyacaktır. Vakıf üniversitesinin yalnızca tüzel kişiliği devam etmemekte, bunun sonucu olarak tüzel kişilik devam ettiği sürece vakıf üniversitesinden devredilen öğrenciler, o vakıf üniversitesinde öğrenimini tamamlamış gibi yine vakıf üniversitesinin diplomasını almaktadır (Vakıf Yükseköğretim Kurumları Yönetmeliği, m.27/4). Dolayısıyla aslında vakıf üniversitesinin eğitim ve öğretim faaliyetleri öğrencilerin devredildiği devlet üniversitesi tarafından vakıf üniversitesi tüzel kişiliği altında yerine getirilmektedir. Ancak belirtmek gerekir ki, vakıf üniversitesinin yönetimi devredilen devlet üniversitesinin yöneticilerine geçtiğinden, devlet üniversitesi tarafından vakıf üniversitesince daha

3 Yönetmeliğin ilgili fikrasında geçen “Bakanlar Kurulu Kararı” ibaresi, 2018'de yürürlüğe giren Anayasa değişikliği sonrasında alınan kararlar için "Cumhurbaşkanı Kararı” olarak kabul edilecektir. 
önce yürürlüğe konulan düzenleyici işlemler değiştirilerek devlet üniversitesinin kendi mevzuatıyla uyumlu hale getirilebilecektir. O zamana kadar ise devri yapılan vakıf üniversitesi öğrencilerine devirden önceki mevzuat hükümleri uygulanmaya devam edecektir.

Vakıf üniversitesinin düzenleyici işlemlerinin öğrencilerin devredildiği üniversitenin kendi mevzuatıyla uyumlu hale getirilmesi, her iki üniversite öğrencilerinin ders programlarının uyumlanmasının ve dolayısıyla üniversitenin akademik personel sayısının yeterliliğinin sağlanması bakımından yerinde olacaktır. Aksi halde öğrencilerin devredildiği devlet üniversitesinde ikili bir düzen oluşturulması gerekecek ve bu durumun üniversiteyi akademik personel açısından zora sokması söz konusu olabilecektir.

\section{4 - Öğrenim Ücretleri ve Bursluluk}

Vakıf Üniversitesinin öğrencileri, vakıf üniversitesinin tüzel kişiliği sona erene kadar vakıf üniversitesince belirlenmiş ücreti ödemeye devam devam edecektir. Ancak artık ücret öğrencinin devredildiği devlet üniversitesinin hesabına yatırılacaktır. Garantör Devlet Üniversiteleri Yönergesi’ nin 8.maddesine göre öğrenim ücreti vakıf üniversitesi tarafından belirlenen ücret üzerinden her yıl TÜFE oranında arttırılacak ve ücret peşin veya taksitle ödenebilecektir. Düzenleme gereğince ücret artırımı yapmakta ve artırım oranını belirlemekte devredilen devlet üniversitesinin herhangi bir takdir yetkisi bulunmamaktadır.

Bununla birlikte Anayasa Mahkemesi 667 sayılı KHK ile kapatılan vakıf üniversiteleri öğrencilerinin yerleştirildiği üniversitelere öğrenim ücreti ödemeye devam etmelerine ilişkin 6749 sayılı Olağanüstü Hal Kapsamında Alınan Tedbirlere İlişkin Kanun Hükmünde Kararnamenin Değiştirilerek Kabul Edilmesine Dair Kanun'un 2.maddesinin 4.fıkrasında yer alan hükmü öğrencilerin vakıf üniversitesine yerleştikleri yılda puanlarına eş ya da daha düşük olan devlet üniversiteleri yönünden bozmuştur.

Karar şu şekilde gerekçelendirilmiştir:

\footnotetext{
"Kural, üniversiteye giriş sınavında aldığı puan itibarıyla devlet üniversitesine yerleşme imkânı varken vakıf yükseköğretim kurumunu tercih eden bir öğrencinin söz konusu vakıf yükseköğretim kurumunun kapatılması sonrasında puanının yeterli olduğu devlet üniversitesine yerleştirilmesi hâlinde buradaki öğrenimine kapatılan vakıf yükseköğretim kurumuna ödediği ücreti ödeyerek devam etmesi sonucunu doğurmaktadır. Söz konusu öğrencilerin yükseköğretim kurumlarına kayıt yaptırdıkları anda aranan başarı sıraları dikkate alındığında bu başarılarına göre devlet üniversitesine kayıt olma hakkım elde ettiklerinden burada bulunan öğrenciler ile kapatılan vakıf yükseköğretim kurumlarından bu şekilde gelen öğrencilerin farklı hukuki durumda oldukları söylenemez. Kural aynı devlet üniversitesine başarı sırasına göre kayıt yaptırma hakkım elde eden öğrencilerden bir kısmına ücret ödeme zorunluluğu getirdiğinden farklı bir muamele öngörmektedir. Söz konusu farklı muamelenin ise makul ve nesnel bir temele dayandığ ${ }_{1}$ söylenemez.
} 
Bu itibarla kapatılan vakıf yükseköğretim kurumuna kayıt yaptırdıkları yılda yapılan merkezî sınavlarda elde ettikleri başarı sıralarına eşit ya da daha az puanla öğrenci kabul eden devlet üniversitelerine öğrencilerin daha önceden ödedikleri ücretleri ödeyerek devam etmeleri eğitim ve öğrenim hakkı bağlamında Anayasa’yla bağdaşmamaktadır.

Açıklanan nedenlerle kural puanı eşit ya da daha düşük devlet üniversiteleri yönünden Anayasa’nın 10., 13. ve 42. maddelerine aykırıdır. İptali gerekir"4.

Anayasa Mahkemesinin bu kararı doğrultusunda faaliyet izni durdurulan vakıf üniversitesi öğrencilerinin vakıf üniversitesine yerleştiği üniversite puanının aynı yıl devredilen devlet üniversitesi puanına eşit ya da bu puandan yüksek olması durumunda, öğrenim ücreti yönünden doğrudan devlet üniversitesine kayıtlanan öğrencilerle aynı koşullarda öğrenim görmesi gerektiği, bunun eşitlik ilkesi gereği olduğu söylenebilecektir. Mahkemenin kararı belirli bir normun denetimine yönelik olsa da gerekçesi aynı durumlara uygulanmasına elverişli bir şekilde açıklanmıştır. Ancak bu konumda bulunan öğrencilerin sayısının yüksek olduğu durumlarda öğrenim ücreti dışındaki burslar için devredilen devlet üniversitesinin ödenek sıkıntısı yaşaması muhtemeldir. Bu durumda öğrencilerin devredildiği devlet üniversitesi vakıf yükseköğretim kurumunun faaliyet izninin kaldırılmasına kendisi karar vermediği halde bu kararın mağduriyetini yaşayacaktır. Bu nedenle garantör üniversiteler için aldıkları öğrenim ücretinin, sağlanan diğer bursları karşılamadı̆̆ı hallerde karşılanamayan kısmı tamamlayıcı bir ödenek sağlanması yerinde olacaktır.

Faaliyet izni kaldırılan vakıf üniversitesi öğrencilerinin ödeyeceği öğrenim ücreti konusunda değinilmesi gereken diğer bir husus ücretin KDV’ye tabi olup olmayacağıdır. 3065 sayılı Katma Değer Vergisi Kanunu’nun 17.maddesi gereğince üniversitelerin eğitim ve öğretim faaliyetleri KDV'den istisna sayılmaktadır. Anılan maddede;

“Genel ve katma bütçeli daireler, il özel idareleri, belediyeler, köyler, bunların teşkil ettikleri birlikler, üniversiteler, döner sermayeli kuruluşlar, kanunla ve Cumhurbaşkanlığı kararnamesiyle kurulan kamu kurum ve kuruluşları, kamu kurumu niteliğindeki meslek kuruluşları, siyasi partiler ve sendikalar, kanunla kurulan veya tüzelkişiliği haiz emekli ve yardım sandıkları, kamu menfaatine yararlı dernekler, tarımsal amaçlı kooperatifler ve Cumhurbaşkanınca vergi muafiyeti tanınan vakıflarin;

a) İlim, fen ve güzel sanatları, tarımı yaymak, islah ve teşvik etmek amacıyla yaptıkları teslim ve hizmetleri”nin katma değer vergisinden muaf olduğu düzenlenmiştir.

$\mathrm{Bu}$ nedenle vakıf üniversitesinden devlet üniversitesine devredilen öğrencilerden alınacak öğrenim ücretine KDV uygulanamayacaktır.

Garantör Devlet Üniversiteleri Yönergesi’nin 8.maddesi 3.fikrasına göre öğrenci öğrenim ücretini faaliyet izni kaldırılan vakıf üniversitesine peşin olarak ödediğini banka dekontu, makbuz, hesap

4 Anayasa Mahkemesi, E.2016/205, K.2019/63, T.24.07.2019, www.kazanc1.com.tr. 
ekstresi veya pos cihazları tarafından üretilen evrak gibi bir belgeyle ispatladığı müddetçe öğrenciden ilgili yıla ait öğrenim ücreti talep edilmeyecektir.

2547 sayılı Kanun'un ek 11.maddesi 3.fıkrasına göre vakıf üniversitesinden devredilen öğrencilerin eğitim-öğretim ücretinde bursluluk durumları gözetilecektir. Bu durumda burslu olarak vakıf üniversitesine yerleştirilmiş öğrenci, devredilen üniversitede de bursluluk durumu devam ettiği sürece öğrenim ücreti ödemeyecektir. Ancak Garantör Devlet Üniversiteleri Yönergesi’nin 8.maddesinin 4.fikrasına göre burslu öğrenci Türkçe eğitim yapan bir programdan kendi isteğiyle yabancı dilde eğitim yapan bir programa geçiş yaptıysa, hazırlık sınıfı için faaliyet izni kaldırılan vakıf üniversitesince belirlenmiş öğrenim ücretini ödeyecektir.

Ayrıca faaliyet izni kaldırılan vakıf üniversitesine yerleştirilirken tanınan bursluluk hakkı mevzuata göre yalnızca öğrenim ücreti bakımından geçerliliğini taşıyacaktır. Garantör Devlet Üniversiteleri Yönergesi’nin 8.maddesi 6.fıkrasına göre öğrenim ücreti bursu dışında öğrenciye vakıf üniversitesinde sağlanan tercih, yemek, yurt gibi diğer özel desteklerin karşılanması hususunda karar verme yetkisiyse devredilen üniversiteye verilmiştir. Ancak öğrenim ücreti bursu dışındaki bursların karşılanmaya devam etmesinde karar yetkisi devredilen üniversiteye bırakılmışsa da, kazanılmış hak teşkil eden burslar söz konusu olursa bunlara dokunulmaması gerekecektir. Zira kazanılmış hak ${ }^{5}$ ilkesine göre, Yönerge’nin yürürlük tarihinden önce mevcut düzenlemelerle elde edilen bursların korunması gerekmektedir. Bununla birlikte öğrenim görmeye hak kazandı̆̆ 1 Vakıf Üniversitesi’nin öğrenimi esnasında kapatılabileceği vb. ihtimalleri düşünmesini öğrencilerden beklemek ve tercihlerini buna göre yapmasını ummak kanımızca adil bir sonuç doğurmayacaktır. Bu nedenle teknik olarak kazanılmış hak teşkil etmeyen durumlarda da devredilen devlet üniversitesinin bunu gözeterek, bursların devamına karar vermesi mağduriyetlerin engellenmesini sağlayacağı gibi, idareye güven ilkesi bakımından da yerinde olacaktır. Ancak mevcut düzenlemeler gereği olmamasına rağmen faaliyet izni sona eren Vakıf Üniversitesince öğrencilere yapılmış indirim, teşvik vb. özel desteklerin bu kapsamda düşünülmesi mümkün görünmemektedir.

\section{III.SONUÇ}

Mevzuatımızda vakıf üniversitelerinin faaliyet izninin kaldırılması durumunda üniversitenin mevcut öğrencilerinin devrinden sonra eğitim öğretim faaliyetlerine ilişkin düzenlemeler bulunmakla birlikte, bu düzenlemelerin detaylı olmadığı, yetersiz kaldığı ve eksik yapıldığ görülmektedir.

Bir üniversitenin öğrencilerinin başka bir üniversiteye devri, üniversitede uygulanan sistem ve programlar arasındaki farklılıklar vb. nedenlerle öğrenim görülecek programın belirlenmesi, uygulanacak mevzuat gibi birçok alanda sorun doğurma potansiyeli taşımaktadır. Mevzuatta bu

5 Kazanılmış haklar, yeni düzenlemeden önce yürürlükte olan yasa veya diğer düzenlemelerle bütün sonuçlarıyla fiilen elde edilmiş olan haklar olarak ifade edilmektedir. Bknz.Turan Yıldırım, 'İdari İşlemler’ in Turan Yıldırım, "İdari İşlemler”, Turan Yıldırım(ed.), İdare Hukuku içinde, İstanbul: On İki Levha Yay., 2020, s.505. Hukuk kurallarıyla oluşturulan ve hukuksal sonucu gerçekleşen statülerin korunacağına ilişkin daha ayrıntılı bilgi için bakınız. Onur Karahanoğulları, İdarenin Hukukla Kavranması: Yasallık ve İdari İşlemler (Yargı Kararlarına Dayalı Bir İnceleme), Ankara: Turhan Kitabevi, 2018, s.558-559. 
konuya ilişkin gerekli tüm düzenlemeler yapılmadan uygulamaların sürdürülmesi ve uygulamada sorun çıktıkça konunun parça parça çözümlenmesi, hem farklı uygulamaların ortaya çıkmasına hem de mevcut kurumlara güvenerek geleceğini biçimlendirmeye çalışan öğrencilerin hak kaybına uğramasına neden olabilecektir. Mevcut halinde olduğu gibi tereddütte kalınan her somut olayda Yükseköğretim Kuruluna danışılması yerine, uygulamada yaşanan ve gelecekte yaşanabilecek tüm sorunlar dikkate alınarak yeni ve tek bir düzenleme kapsamında konunun ayrıntılı olarak düzenlenmesi hukuki öngörülebilirlik açısından yerinde olacaktır.

\section{KAYNAKÇA}

Karahanoğulları, Onur, İdarenin Hukukla Kavranması: Yasallık ve İdari İşlemler (Yargı Kararlarına Dayalı Bir İnceleme), Ankara: Turhan Kitabevi, 2018

Önüt, Lale Burcu, "Vakıf Üniversitesinin Faaliyetlerinin Durdurulması ve Garantör Üniversitenin İşlevi”, İKÜHFD, C.17, S.1, Y.2018.

Yıldırım, Turan, "İdari İşlemler”, Turan Yıldırım (Ed.), İdare Hukuku içinde, İstanbul: On İki Levha Yay., 2020.

Yıldırım, Turan, "Vakıf Üniversitelerinin Denetlenmesi”, MÜHF-HAD, C.21, S.2, Y.2015.

www.kazanci.com.tr. 